\title{
Opportunities and Obstacles for Providing Medical Education Through Social Media
}

Aimee Wilkinson, BSc; James Ashcroft, MBChB

Imperial College London, London, United Kingdom

Corresponding Author:

Aimee Wilkinson, BSc

Imperial College London

Surgical Innovation Centre

St Mary's Hospital

London, W21NY

United Kingdom

Phone: 447543078801

Email: arw1318@ic.ac.uk

\section{Abstract}

Social media has infiltrated almost every sector of life, and medical education is no exception. As this technology becomes mainstream within society, an increasing number of health care students and professionals are using it for learning. Several important considerations for the risks of this technology are discussed here.

(JMIR Med Educ 2019;5(2):e15297) doi: 10.2196/15297

\section{KEYWORDS}

medical education; social media; innovation

Social media has drastically altered how the world communicates. No longer a matter of science fiction, large quantities of public and private data can now be exchanged in minutes. A recent Journal of Medical Internet Research report examined the successes of the YouTube channel "Not Just a Medical Student," which attempts to innovatively apply social media for the advancement of medical education [1]. As a recently graduated doctor and current undergraduate medical student who regularly use social media for medical education, we would like to share our perspectives on this report and future advances within this field.

Medical school curricula often lack teaching on leadership, teamwork, and innovation, all of which could be taught through social media. Despite saturated curricula, these elements are key to health care advancement and of particular importance when undertaking leadership or innovation roles after graduation. More broadly, the benefits of educational social media are clear. By overcoming geographical and time barriers, it allows students equal access to teaching and is associated with higher levels of student satisfaction [2]. Social media platforms have a further advantage over conventional communication methods, in that these online spaces are already accessed as part of users' daily routines [2,3]. For example, it is estimated that $44.5 \%$ of medical trainees and $64.3 \%$ of medical students have active Facebook accounts [4].
The application of social media to medical education is not without risks. Professionals and patients alike are susceptible to false information, and such content can easily be distributed if time is not taken for validation and peer review. These strategies are further important to safeguard the professional reputations of individuals and institutions. Without considering regulation and the need for a clear distinction between personal and professional opinion, public perception of medical practice may be affected and patients could be dissuaded from choosing truly beneficial treatments. Lack of regulation further permits the spread of biased information, such as exaggerated or misleading claims from industries with financial interests. Finally, discussion of real cases risks physicians accidentally sharing personal information and thereby breaching confidentiality. A survey of 1600 health science staff and students found that the greatest barriers to educational social media use were concerns about policies and professionalism [3]; hence, training is required to address these concerns and prevent doctors from becoming liable for damages. Overall, a compromise on speed is warranted to ensure that all content adheres to guidance from regulatory bodies before publication.

Future work should address the lack of quantitative evidence to support claims that social media is an effective educational tool [5]. The presently used metrics, such as the number of likes, shares, and comments a post receives, require assessment to 
decipher why exactly an audience deems a video favorable or shareable, and research into whether these metrics are indicative of educational value is needed. We believe that social media is a powerful tool with the potential to improve medical education and the lives of patients worldwide. We thank the "Not Just a Medical Student" team for producing such innovative content and look forward to seeing how this field progresses.

\section{Conflicts of Interest}

None declared.

\section{References}

1. Abbas N, Ojha U. Not Just a Medical Student: Delivering Medical Education Through a Short Video Series on Social Media. JMIR Med Educ 2019 May 06;5(1):e11971 [FREE Full text] [doi: 10.2196/11971] [Medline: 31066690]

2. Pander T, Pinilla S, Dimitriadis K, Fischer M. The use of Facebook in medical education--a literature review. GMS Z Med Ausbild 2014;31(3):Doc33 [FREE Full text] [doi: 10.3205/zma000925] [Medline: 25228935]

3. O'Sullivan E, Cutts E, Kavikondala S, Salcedo A, D'Souza K, Hernandez-Torre M, et al. Social Media in Health Science Education: An International Survey. JMIR Med Educ 2017 Jan 04;3(1):e1 [FREE Full text] [doi: 10.2196/mededu.6304] [Medline: 28052842]

4. Thompson L, Dawson K, Ferdig R, Black E, Boyer J, Coutts J, et al. The intersection of online social networking with medical professionalism. J Gen Intern Med 2008 Jul;23(7):954-957 [FREE Full text] [doi: 10.1007/s11606-008-0538-8] [Medline: 18612723$]$

5. Whyte W, Hennessy C. Social Media use within medical education: A systematic review to develop a pilot questionnaire on how social media can be best used at BSMS. MedEdPublish 2017;6(2) [FREE Full text] [doi: 10.15694/mep.2017.000083]

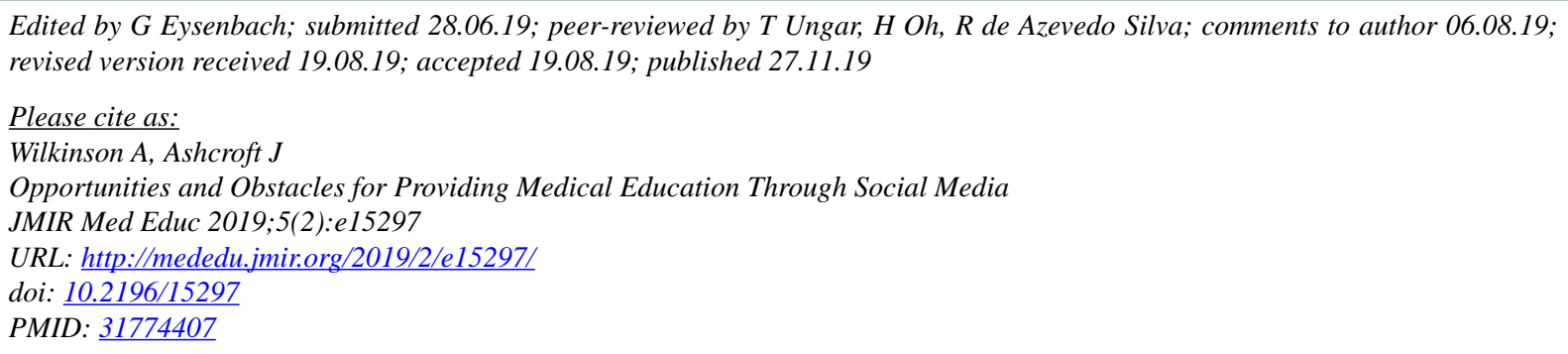

(C)Aimee Wilkinson, James Ashcroft. Originally published in JMIR Medical Education (http://mededu.jmir.org), 27.11.2019. This is an open-access article distributed under the terms of the Creative Commons Attribution License (https://creativecommons.org/licenses/by/4.0/), which permits unrestricted use, distribution, and reproduction in any medium, provided the original work, first published in JMIR Medical Education, is properly cited. The complete bibliographic information, a link to the original publication on http://mededu.jmir.org/, as well as this copyright and license information must be included. 